\title{
ARTICLE
}

\section{Methodology for Preconcentration and Determination of Silver in Aqueous Samples using Cloud Point Extraction}

\author{
Ebaa Adnan Azooz iD, Ghusoon Jawad Shabaa² iD, Emad Abbas Jaffar Al-Mulla*3 $\square$ \\ ${ }^{1}$ Department of Chemistry, The Gifted Students' School in Najaf, Ministry of Education, Iraq \\ ${ }^{2}$ College of Medicine, Jabir Ibn Hayyan Medical University, Najaf, Iraq \\ ${ }^{3}$ Pathological Analysis Techniques, Faculty of Health and Medical Techniques, Al-Furat Al-Awsat \\ Technical University, Kufa, An-Najaf, Iraq
}

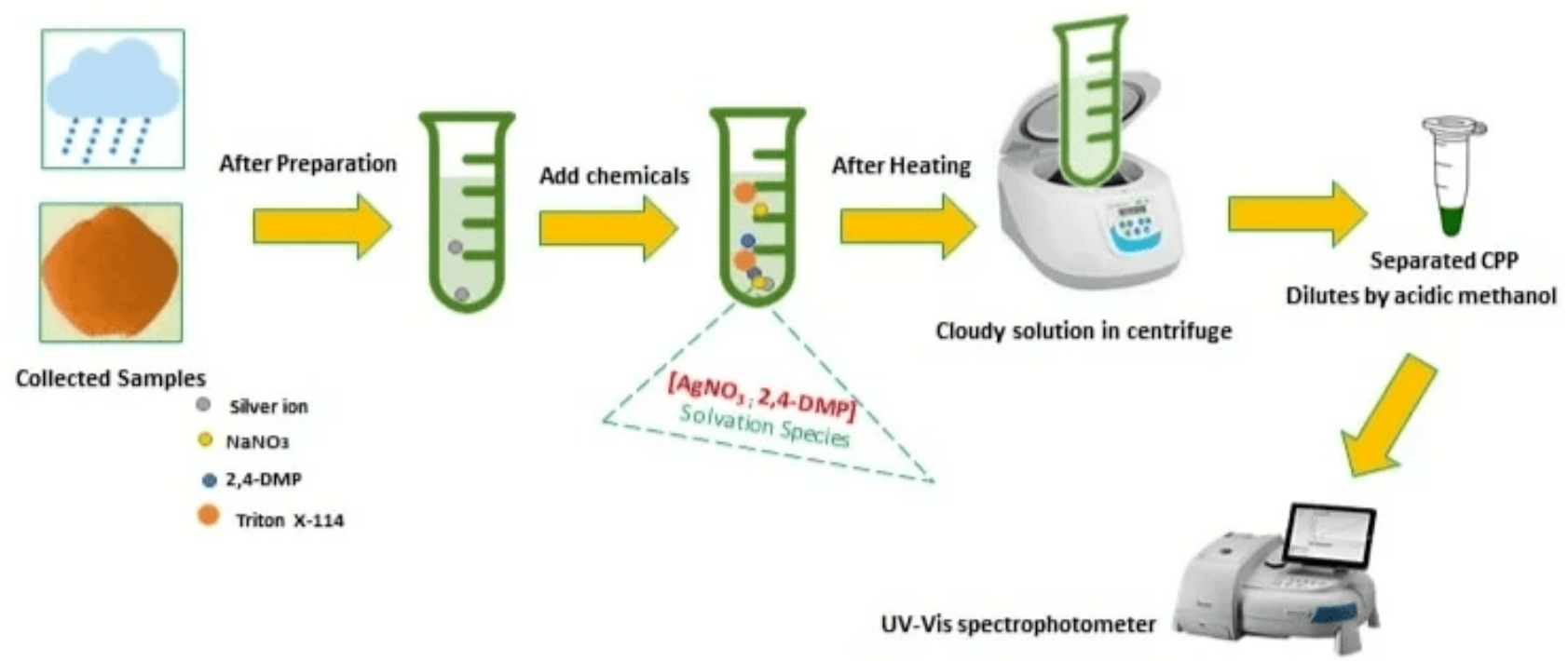

For the selective extraction of silver, a cloud point extraction (CPE) procedure was developed. After synthesizing the solvation species through the reaction of silver ions with 2, 4-dimethyl pentane-3-one (2,4 DMP), the salting-out agent $\left(0.4 \mathrm{~mol} \mathrm{~L}^{-1} \mathrm{NaNO}_{3}\right)$ was added at $35^{\circ} \mathrm{C}$ and, after $10 \mathrm{~min}$, Triton $\mathrm{X}-114$ was used to separate silver ions from aqueous solution. The type and quantity of salting-out agent, silver ion, temperature, heating time, and surfactant volume were all examined as important factors determining the $\mathrm{CPE}$. The analytical curve in the $0.1-100 \mu \mathrm{L} \mathrm{L}^{-1} \mathrm{Ag}$ range was straight at optimal conditions. The detection limit (LOD), quantification limit (LOQ), and enrichment factor (E) were $0.05 \mu \mathrm{g} \mathrm{L}^{-1}, 0.15 \mu \mathrm{g} \mathrm{L}^{-1}$, and 200, respectively. The relative standard deviation (RSD) was estimated as $0.2-3.9 \%(n=5)$ in relation to 1,40 ,

Cite: Azooz, E. A.; Shabaa, G. J.; Al-Mulla, E. A. J. Methodology for Preconcentration and Determination of Silver in Aqueous Samples using Cloud Point Extraction. Braz. J. Anal. Chem. 2022, 9 (35), pp 39-48. http://dx.doi.org/10.30744/brjac.2179-3425. AR-61-2021 
and $80 \mu \mathrm{g} \mathrm{L}^{-1} \mathrm{Ag}$. Flame atomic absorption spectrometry and spectrophotometry exploiting dithizone were used to assess the CPE accuracy. The proposed approach was then applied to river water, rain water and sand samples.

Keywords: cloud point extraction, salting out effect, silver, solvation system, solvent extraction.

\section{INTRODUCTION}

Non-polluting and accurate methods for trace element determination are desirable [1,2]. To remove and extract tiny quantities of elements, a variety of approaches have been utilized [3-5], including solid-phase extraction [6,7], liquid-phase extraction [8-12], and cloud point extraction (CPE) [13-16]. Researchers are interested in CPE because it follows green chemistry principles. After all, the chemicals utilized are tiny and non-toxic. CPE also low-cost, accurate, efficient, and quick [17-22]. Achieving a critical micellar concentration $(\mathrm{CMC})$ requires a cloud point temperature that is just right. Cloud point phase (CPP) (nonhydrophilic, with large micelle quantity and tiny volume) and an aqueous phase (large volume, hydrophilic nature) are produced as a result. To create hydrophobic complexes, target components are combined with an organic chelating reagent, which is further transported towards CPP [23-25]. Solvation molecules have hydrophobic properties and can be equally distributed in the micelle phase [13]. In the condition of salting-out processes, nitrate and hydrophobic reagents [ $\mathrm{M}\left(\mathrm{NO}_{3}\right)_{x}$; b (organic reagent)] are combined. Many agents, including aldehydes, ketones, asters, etc. Generally, the salting-out process is caused by ions desorbing from the hydrophilic portions of micelles, enhancing inter-micelle attraction and, as a result, causing surfactant molecules to precipitate. The salting-out effect was absence and presence of $\mathrm{NaNO}_{3}$, $\mathrm{KNO}_{3}$, and other chemicals. The solution ionic strength is mostly influenced by nitrate salts, which reduce the hydration shell surrounding metallic ions and aid in the transport of ionic species to CPP [26-28].

Silver is antibiotic, thermally and electrically conductive. Silver compounds are commonly utilized in water purification filters, medical materials, food, and advanced materials. Because the amount of silver in the crustal ground is low, water naturally includes trace amounts of it. As a result, a particularly sensitive methodology should be utilized for silver detection in water for evaluating the toxicity effect in bio-organisms [30,31]. In this instance, an ultrasound-assisted cloud point extraction procedure was implemented. Silver was extracted from samples using copolymer and $\mathrm{Fe}_{3} \mathrm{O}_{4}$ nanoparticles at $\mathrm{pH} 5.0$, and spectrophotometrically detected. The detection limit (LOD) was $0.85 \mathrm{\mu g} \mathrm{L}^{-1}$ [32].

The primary goal of this study was to extract and determine silver in water and sand samples using CPE. The surfactant, chelating, and salting-out reagents were Triton X-114, 2, 4-DMP and $\mathrm{NaNO}_{3}$, respectively. The factors that influence CPE were examined.

\section{MATERIALS AND METHODS Reagents and solutions}

All the substances (with purity ranging from 99.0 to $99.2 \%$ ) used in this study were from Merck, Darmstadt, Germany. Deionized water was used in the preparation of all samples and solutions. A standard solution $1.00 \mathrm{~g} \mathrm{~L}^{-1} \mathrm{Ag}$ was prepared by dissolving $\mathrm{AgNO}_{3}$ with water in the presence of $1 \mathrm{~mL}$ of $\mathrm{HNO}_{3}$. Then, the solution was transferred to a suitable volumetric flask and the volume was completed to the mark using water. The 2,4-DMP solution $\left(1 \times 10^{-2} \mathrm{~mol} \mathrm{~L}^{-1}\right)$ was prepared in water which contains drops of surfactant. The $\mathrm{NaNO}_{3}$ solution $\left(1.00 \mathrm{~mol} \mathrm{~L}^{-1}\right)$, was prepared in water. The dithizone solution $\left(1 \times 10^{-2} \mathrm{~mol} \mathrm{~L}^{-1}\right)$ was prepared in $\mathrm{CCl}_{4}$.

\section{Instrumentation}

A water bath model Cambridge, England, (WNB7-45), ( $\pm 0.0001 \mathrm{~g}$ precision) A and D company, Japan, a UV-Vis Biochrom spectrophotometer Libra, S60 (Cambridge, England), and an AA 6800 Shimadzu flame atomic absorption spectrophotometer (Kyoto, Japan) with a silver hollow cathode lamp were employed. 


\section{Test methodology}

An aliquot comprising $25 \mathrm{~mL}$ of an aqueous solution, $100 \mu \mathrm{g} \mathrm{L}^{-1}$ silver ions, $0.4 \mathrm{~mol} \mathrm{~L}^{-1} \mathrm{NaNO}_{3}, 1 \times 10^{-4}$ mol L-1 2,4-DMP solution, and $0.5 \mathrm{~mL}$ of Triton X-114 were mixed and deionized water was diluted to the line of the $50 \mathrm{~mL}$ centrifuge tube. This was done in a water bath to accelerate the formation of the micelle at $35{ }^{\circ} \mathrm{C}$ for $10 \mathrm{~min}$. The mixture was centrifuged for 12 minutes at $4000 \mathrm{rpm}$ and then refrigerated for 4.0 minutes in the freezer. Then, the hydrophobic phase was separated and $5 \mathrm{~mL}$ of an acidic methanol solution containing nitric acid $\left(1.0 \mathrm{~mol} \mathrm{~L}^{-1}\right)$ was added. Afterward, the absorbance was measured at $\lambda_{\max }=$ $325 \mathrm{~nm}$. A blank solution was prepared and analyzed in the same way.

To extract silver ions from aqueous solutions, the dithizone $\left(\mathrm{H}_{2} \mathrm{Dz}\right)$ methodology [41] was employed. The $0.001 \% \mathrm{H}_{2} \mathrm{Dz}$ in $\mathrm{CCl}_{4}$ was added to a silver solution containing $\mathrm{HNO}_{3}$ until the concentration reached 1-2 $\mathrm{mol} \mathrm{L}^{-1}$, then shacked for 5 minutes. The step was fivefold repeated. The color of an aqueous solution after the last amount of $\mathrm{H}_{2} \mathrm{Dz}$ has been added should not change. Separation of the silver-containing aqueous layer by lowering the $\mathrm{pH}$ to $4-5$ with ammonia, then removing the silver in $\mathrm{CCl}_{4}$ with $0.001 \% \mathrm{H}_{2} \mathrm{Dz}$. To exclude any residual $\mathrm{H}_{2} \mathrm{Dz}$ from the sample, a dilute ammonia solution (2 drops of conc. $\mathrm{NH}_{3}$ solution in $25 \mathrm{~mL}$ of water) was utilized [42]. The analytical curve was used to determine the amount of silver ions. Equation 1 gives the distribution ratio (D). Log $D$ data is placed in all of the graphics to provide more structured and wide data [33].

$$
D=\frac{[A g(I)] C P P}{[A g(I)] a q}
$$

\section{Sample Preparation}

Water samples

All water samples were filtered through a $0.45 \mu \mathrm{m}$ Millipore filter and stored in a polyethylene container for future application after being acidified to $\mathrm{pH} 2.0$ with $\mathrm{HNO}_{3}$ to reduce silver ions adsorption on the container surface.

\section{Sand samples}

The sand samples were gathered from several sites throughout the Najaf desert in Iraq. The samples were dehydrated and mashed at $90{ }^{\circ} \mathrm{C}$ for 15 hours before being put through a 130 grit filter. In a Teflon bottle, $5 \mathrm{~mL}$ of each $\mathrm{HNO}_{3}, \mathrm{H}_{2} \mathrm{O}_{2}$, and $\mathrm{H}_{2} \mathrm{O}$ of the measuring sand were added to $1.5 \mathrm{~g}$ and destroyed using a microwave digestion oven with an application cooking program [25]. The extra $\mathrm{H}_{2} \mathrm{O}_{2}$ was then neutralized using $20 \mathrm{~mL}$ of $\mathrm{H}_{3} \mathrm{BO}_{3}(5 \% \mathrm{w} / \mathrm{v})$. After that, the mixture was filtered, and the volume was filled up to $50 \mathrm{~mL}$. Masking reagents $\left(\mathrm{KCN}\right.$ and $\mathrm{K}_{2} \mathrm{~S}_{2} \mathrm{O}_{3}$ ) were applied to samples at a concentration of $0.1 \mathrm{~mol} \mathrm{~L}^{-1}$ [25].

\section{RESULTS AND DISCUSSION}

The spectrophotometric investigation involved $50 \mathrm{~mL}$ of aqueous solutions containing $100 \mu \mathrm{L} \mathrm{L}^{-1} \mathrm{Ag}(\mathrm{I})$, $0.4 \mathrm{~mol} \mathrm{~L}^{-1} \mathrm{NaNO}_{3}, 1.0 \%$ Triton X-114 and $1 \times 10^{-4} \mathrm{~mol} \mathrm{~L}^{-1} 2,4-\mathrm{DMP}$. The heating temperature was maintained as $35^{\circ} \mathrm{C}$ for 10 minutes. The extracted components were spectrophotometrically evaluated $\left(\lambda_{\max }=325\right.$ $\mathrm{nm})$. Effects of the main involved factors were investigated for dimensioning the proposed procedure.

\section{Influence of the sodium nitrate concentration}

Aqueous solutions $(50 \mathrm{~mL})$ including $100 \mu \mathrm{g} \mathrm{L}^{-1}$ silver ions were handled with different quantities of salting-out $\left(\mathrm{NaNO}_{3}\right)$ in the range of $\left(0.1-1 \mathrm{~mol} \mathrm{~L}^{-1}\right)$ according to the test methodology at $40{ }^{\circ} \mathrm{C}$ for 15 minutes. After treating the $\mathrm{Ag}(\mathrm{I})$ aqueous solutions as above described, it was realized that $0.4 \mathrm{~mol} \mathrm{~L}^{-1}$ was the most effective concentration of the salting-out agent $\left(\mathrm{NaNO}_{3}\right)$. This concentration corresponded to the fastest formation equilibrium with the development of solvation species. This was not attained with a concentration just under or higher than the optimal value. Equation 2 depicts the structure of solvation species. Figures 1 and 2 show the influence of $\mathrm{NaNO}_{3}$ concentrations on salting-out. 


$$
\mathrm{Ag}^{+}+\mathrm{NO}_{3}^{-}+2,4-\mathrm{DMP} \rightleftharpoons\left[\mathrm{AgNO}_{3}, 2,4-\mathrm{DMP}\right]
$$

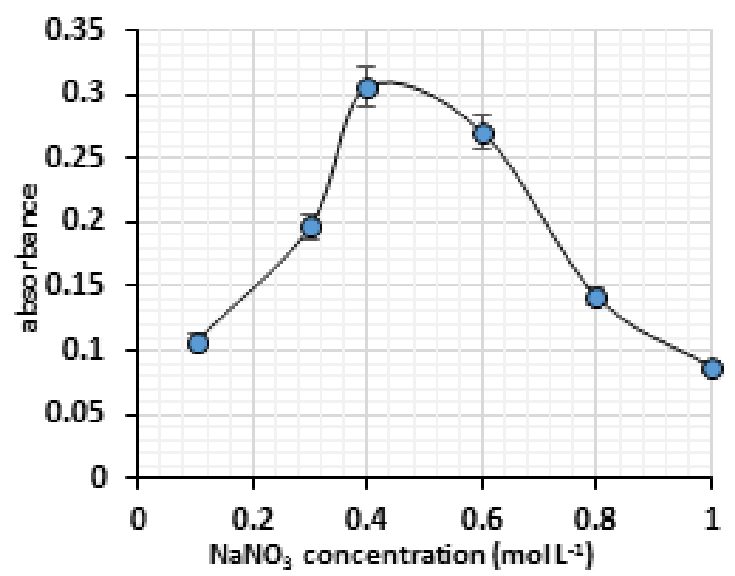

Figure 1. Influence of the $\mathrm{NaNO}_{3}$ concentration on the extraction efficiency.

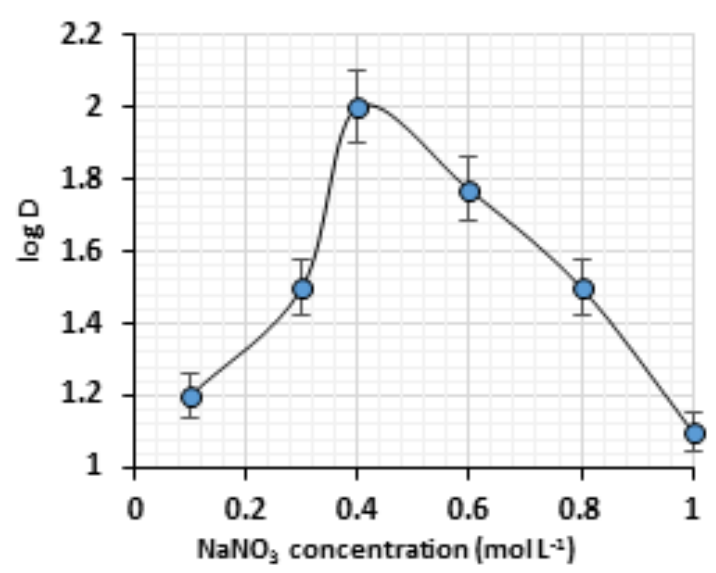

Figure 2. Influence of the $\mathrm{NaNO}_{3}$ concentration on the $\mathrm{D}$.

\section{Influence of the concentration of the silver ions}

Figures 3 and 4 display the effectiveness of silver ion solutions at different concentrations $\left(0.1-100 \mathrm{ug} \mathrm{L}^{-1}\right)$ including $0.4 \mathrm{~mol} \mathrm{~L}^{-1} \mathrm{NaNO}_{3}$, and completing the task according to the applied methodology. The findings show that silver ions act a parameter that influences the thermodynamic equilibrium of the synthesis solvation species, as well as the transport to the micelle. The optimal concentration amount of silver was then found as $100 \mu \mathrm{g} \mathrm{L}^{-1}$ and this result is in agreement with references [33,41].

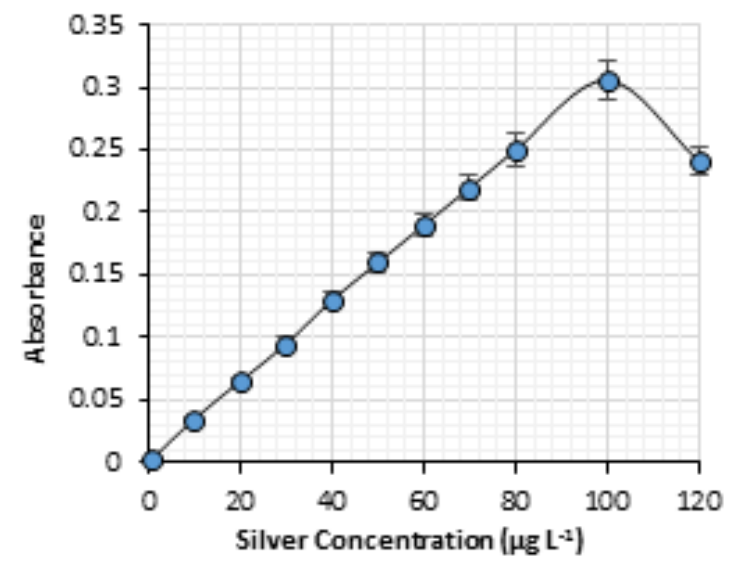

Figure 3. Influence of the silver ion concentration on the absorption of solvation species.

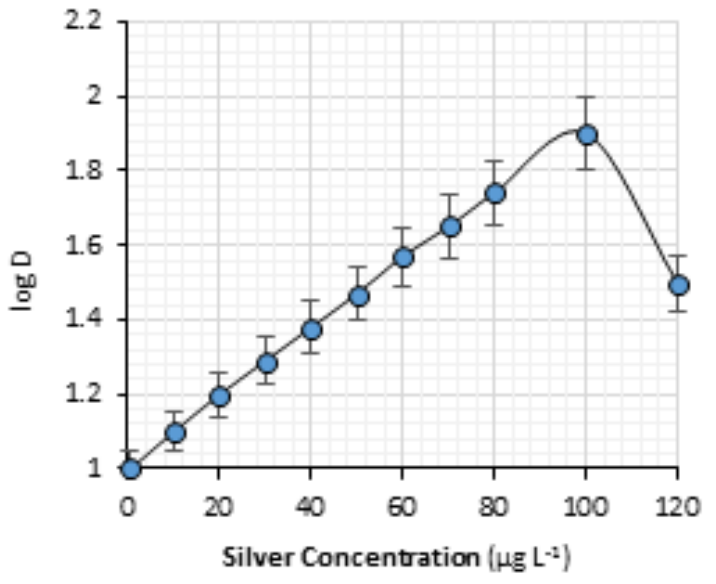

Figure 4. Influence of the silver ion concentration on extraction efficiency.

\section{Influence of the ketone nuture}

Five different ketones were tested as organic agents $\left(1 \times 10^{-4} \mathrm{~mol} \mathrm{~L}^{-1}\right)$ for the formation of solvation species with silver nitrate separation according to the test methodology. The results in Table I show a different extraction efficiency using different ketones. The 2,4-DMP appears to be the best value for $D$ and absorbance depends on chemical structure [34]. It increases the lipophilic properties of solvation species, which allows transfer to the CCP for easy separation. It permits the preconcentration at a specific 
temperature with the presence of a salting-out impact. 2,4-DMP was then selected to be used in the following studies.

\begin{tabular}{lccc} 
Table I. Effects of various ketones on the extraction efficiency and distribution ratio (D) \\
\hline Ketones & $\boldsymbol{\lambda}_{\max } \mathbf{n m}$ & Absorbance & D \\
\hline 2,4-DMP & 325 & 0.342 & 95.460 \\
Acetone & 256 & 0.105 & 43.461 \\
Acetophenone & 291 & 0.201 & 54.621 \\
Methyl Iso Butyl Ketone & 292 & 0.247 & 80.752 \\
Propanone & 297 & 0.233 & 75.500 \\
\hline
\end{tabular}

\section{Influence of the temperature and heating time}

In CPE, temperature and heating time are important parameters. Figure 5 refers to a thorough process for extracting silver ions at various temperatures. The ideal temperature was selected as $35^{\circ} \mathrm{C}$. Thus, it was suitable for forming a hydrophobic CPP and provided enhanced extraction efficiency for silver ion removal [33,34]. Enthalpy, entropy and Gibbs free energy were then determined as $\Delta H_{e x}=0.0959 \mathrm{~kJ} / \mathrm{mol}$, $\Delta \mathrm{S}_{\mathrm{ex}}=200.668 \mathrm{~J} / \mathrm{mol}$ and $\Delta \mathrm{G}_{\mathrm{ex}}=-77.655 \mathrm{~kJ} / \mathrm{mol}$.

Then, under selected conditions for all chemical concentrations and temperatures, the CPE procedure was used to determine various heating times ranging from 5 to 30 minutes (Figure 6). The selected heating time was 10 minutes. Heating time offers the required energy to receive the right rate of thermodynamic equilibrium for the synthesis of solvation species, and higher extraction efficiency [14,15].

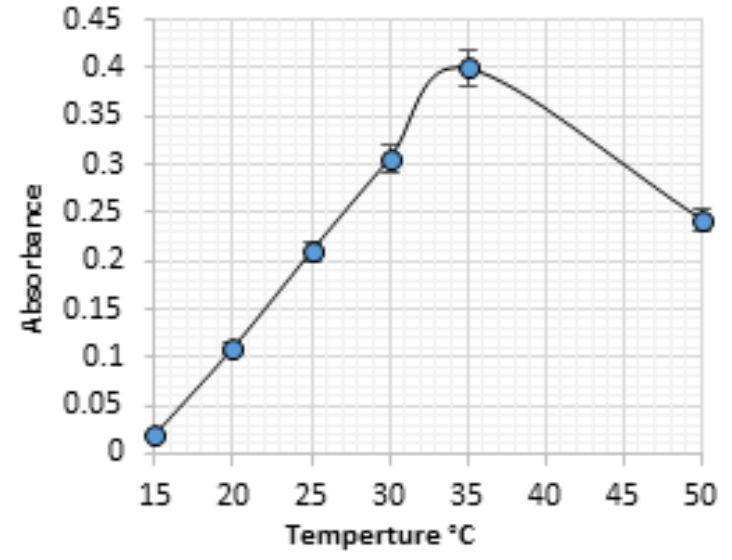

Figure 5. Influence of the temperature on extraction efficiency.

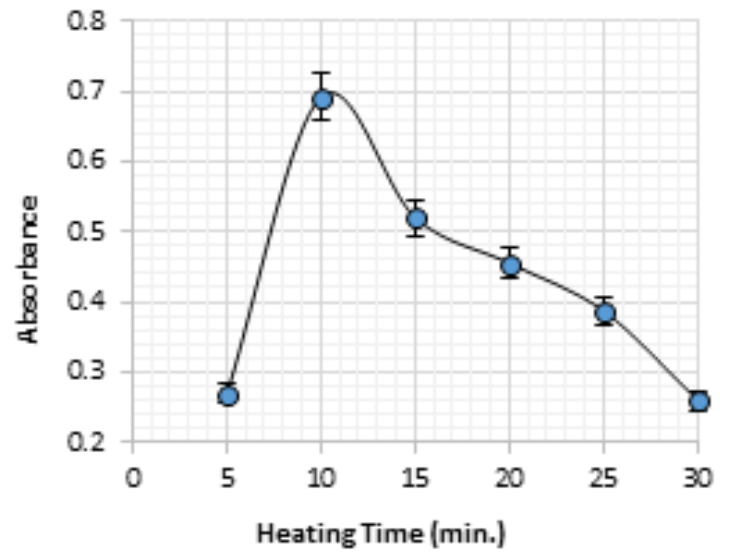

Figure 6. Influence of the heating time on extraction efficiency.

\section{Influence of the Triton X-114 volume}

Some features of the non-ionic surfactant Triton X-114, such as lipophilicity and ability to endure the electrolytes caused by corresponding silver ions, enabled the CPE and analytical selectivity for silver ions $[33,34]$. Figures 7 and 8 show the influence of Triton $X-114(1.0 \% \mathrm{v} / \mathrm{v})$ at various volumes $(0.1-1.0 \mathrm{~mL})$. Better results, such as a high extraction efficiency, were obtained with $0.5 \mathrm{~mL}$ of Triton $\mathrm{X}-114$, as the critical micellar concentration (CMC) was surpassed. 


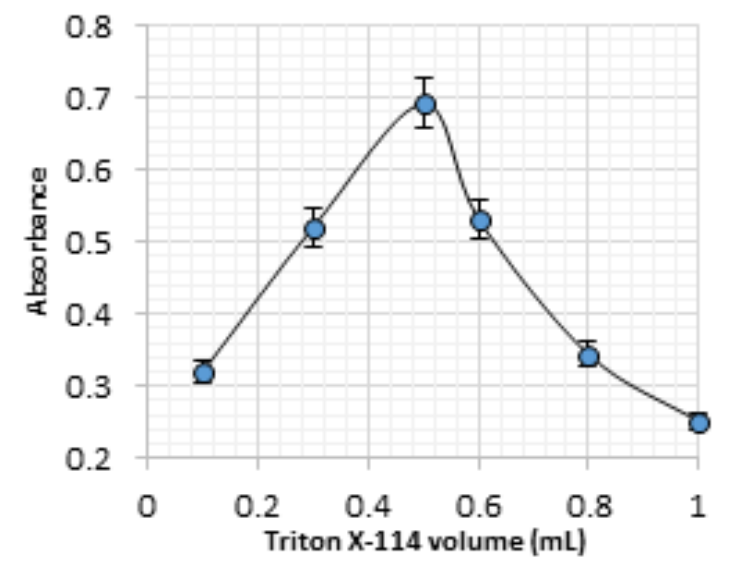

Figure 7. Influence of the Triton X-114 volume on the absorbance of extracted species.

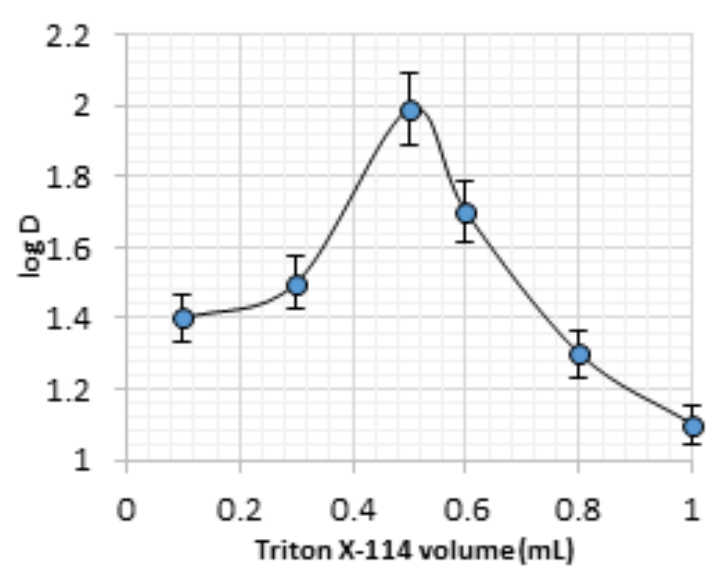

Figure 8. Influence of the Triton $\mathrm{X}-114$ volume effect on D.

\section{Comparison with other procedures}

Some parameters of the proposed CPE, such as organic ligands, LOD and E were compared with those related to other strategies for preconcentration of silver ions using Triton X-114 as a surfactant [25, 33-44]. Table II summarizes the results. It can be seen that the LOD of the present method is lower, in relation to other procedures $[35,37,39,45]$, whereas the best LOD was obtained by the CPE method [36]. The large and excellent $E$ is probably due to the higher extraction efficiency of silver ions.

Table II. Comparison of Procedures for Silver Determination using CPE and Triton X-114

\begin{tabular}{|c|c|c|c|}
\hline Organic ligands & LOD & E & References \\
\hline 2,4-DMP & $0.05 \mu \mathrm{g} \mathrm{L}^{-1}$ & 200 & this work \\
\hline 6-(4-BrPAA) & $0.0054 \mu \mathrm{g} \mathrm{mL}^{-1}$ & 12.4 & [44] \\
\hline AgNPs & $1.50 \mathrm{ng} \mathrm{L}^{-1}$ & - & [38] \\
\hline APDC & $0.42 \mu \mathrm{g} \mathrm{L}^{-1}$ & 20 & [35] \\
\hline BIES & $1.40 \mathrm{ng} \mathrm{mL}^{-1}$ & 42 & [43] \\
\hline BIMPI & $10.00 \mu \mathrm{g} \mathrm{L}^{-1}$ & 35 & [37] \\
\hline BMAA & $0.43 \mathrm{ng} \mathrm{mL}^{-1}$ & - & [34] \\
\hline DDTC & $1.00 \mu \mathrm{g} \mathrm{L}^{-1}$ & 24 & [45] \\
\hline DDTC & $0.30 \mathrm{ng} \mathrm{mL}^{-1}$ & 33 & [36] \\
\hline $\mathrm{H}_{2} \mathrm{Dz}$ & $0.56 \mathrm{ng} \mathrm{mL}^{-1}$ & 43 & [40] \\
\hline HPCTS & $0.08 \mu \mathrm{g} \mathrm{L}^{-1}$ & 46 & [25] \\
\hline MBT & $2.20 \mathrm{ng} \mathrm{mL}^{-1}$ & - & [33] \\
\hline PAR & $6.00 \mu \mathrm{g} \mathrm{L}^{-1}$ & - & [39] \\
\hline
\end{tabular}

6-(4-BrPAA)6-(4-bromo-phenylazo)m-anisidine, AgNPs silvernanoparticles, APDC ammonium pyrrolidine dithiocarbamate, BIES bis((1H-benzo [d] imidazol-2yl)ethyl) sulfane, BIMPI 2-((2-((1H-benzo[d]imidazole2-yl)methoxy)phenoxy)methyl)-1 $\mathrm{H}$-benzo[d]imidazol, BMAA bis(2-mercaptoanil) acetylacetone, DDTC diethyl dithiocarbamate, $\mathrm{H}_{2} \mathrm{Dz}$ Dithiazone, HPCTS 4-(p-chlorophenyl)-1-(pyridin-2-yl)thiosemicarbazide, MBT 2-mercaptobenzothiazole, PAR 4,2 pyridylazo resorsinol. 


\section{Analytical Figures of Merit}

Limit of detection, limit of quantification, enrichment factor, precision, and linearity of the analytical curve were also examined, and the results are summarized in Table III. Analysis of this table reveals that silver recoveries were quantitative (>98.7\%), so the analytical accuracy was good. For $\mathrm{C}=30 \mu \mathrm{L} \mathrm{L}^{-1}$, RSD was $1.5 \%$, based on five-fold assaying times of a $50 \mathrm{~mL}$ of solution. Under ideal conditions, the linearity was notes within 0.1 and $100 \mu \mathrm{g} \mathrm{L}^{-1}$. The standard error of detection limit detection limit for the blank solution (3.3 S/b) was determined as $0.05 \mu \mathrm{g} \mathrm{L}^{-1}$. Instead, the $E$ was estimated as 200 , by using the ratio of the slopes of the analytical curve after and before CPE.

Table III. Analytical Figures of Merit for CPE

\begin{tabular}{ll}
\hline Parameters & \multicolumn{1}{c}{ CPE } \\
\hline Enrichment factor & 200 \\
Limit of Detection & $0.050 \mu \mathrm{g} \mathrm{L}^{-1}$ \\
Limit of Quantification & $0.15 \mu \mathrm{g} \mathrm{L}^{-1}$ \\
Linearity & $0.1-100 \mu \mathrm{g} \mathrm{L}^{-1}$ \\
Recovery & $99.2-107.1 \%$ \\
Relative Standard Deviation $(\mathrm{n}=5)$ & $0.2-3.9 \%$ \\
\hline
\end{tabular}

CPE conditions: $50 \mathrm{~mL}$ sample, $1 \%(\mathrm{v} / \mathrm{v})$ Triton X-114 (0.5 mL), $0.4 \mathrm{~mol} \mathrm{~L}^{-1} \mathrm{NaNO}_{3}, 1 \times 10^{-4} \mathrm{~mol} \mathrm{~L}^{-1} 2,4-$ DMP, temperature $35^{\circ} \mathrm{C}$ and time $10 \mathrm{~min}$.

\section{Applications}

The proposed innovation was applied to silver determination in natural waters and sand tests from Al-Najaf city. Accuracy was assessed by analyzing samples already run by other methods. CPE was used to allow the estimation of recoveries after addition of known amounts of silver ions to the samples. The results (Table IV) demonstrate the CPE ability to extract and determine silver ions in water tests with various materials in the appropriate conditions, as well its ability to isolate silver ions. Results of sliver of determination by two classical methods (FAAS and UV-Vis spectrophotometry) are also presented. Table $\checkmark$ summarizes the obtained results.

Table IV. Silver determination in river and rain water samples three times

\begin{tabular}{|c|c|c|c|c|c|c|}
\hline \multirow[b]{2}{*}{ Tests } & \multirow{2}{*}{$\begin{array}{l}\text { Added } \\
\left(\mu g L^{-1}\right)\end{array}$} & \multicolumn{3}{|c|}{ CPE } & \multirow{2}{*}{$\begin{array}{l}\text { FAAS } \\
\left(\mu g L^{-1}\right)\end{array}$} & \multirow{2}{*}{$\begin{array}{c}\text { Dithizone } \\
\left(\mu g L^{-1}\right)\end{array}$} \\
\hline & & $\begin{array}{l}\text { Found } \\
\left(\mu g L^{-1}\right)\end{array}$ & RSD (\%) & $\begin{array}{c}\text { Recovery } \\
(\%)\end{array}$ & & \\
\hline \multirow{4}{*}{$\begin{array}{l}\text { Shatt Al-Kufa } \\
\text { water }\end{array}$} & - & N.D. & - & - & & \\
\hline & 2.00 & 1.63 & 2.10 & 99.22 & 2.10 & 1.90 \\
\hline & 4.00 & 4.11 & 0.23 & 107.10 & 4.02 & 3.85 \\
\hline & 6.00 & 5.88 & 1.47 & 99.30 & 6.01 & 6.10 \\
\hline \multirow{4}{*}{ Rainwater ${ }^{b}$} & - & N.D. & - & - & - & - \\
\hline & 2.00 & 2.14 & 0.12 & 98.50 & 2.00 & 1.78 \\
\hline & 4.00 & 4.40 & 1.23 & 102.50 & 4.80 & 4.82 \\
\hline & 6.00 & 6.06 & 1.50 & 100.60 & 6.39 & 6.31 \\
\hline
\end{tabular}

${ }^{b}$ Collected at Al-Najaf city, Iraq (December 2020). N.D. not detected. 
Table V. Silver determination in sand samples by the proposed innovation

\begin{tabular}{cc}
\hline Samples $^{*}$ & $\begin{array}{c}\text { mean } \pm \mathrm{RSD}(\mathbf{n}=\mathbf{5}) \\
\boldsymbol{\mu g ~ L}\end{array}$ \\
\hline 1 & $3.02 \pm 3.40$ \\
2 & $5.88 \pm 1.60$ \\
3 & $3.38 \pm 1.40$ \\
4 & $4.25 \pm 2.90$ \\
5 & $5.01 \pm 0.70$ \\
6 & $3.33 \pm 2.00$
\end{tabular}

*These sand samples were collected from various locations in the Al-Najaf desert.

\section{CONCLUSIONS}

An environmentally friendly, low-cost, and selective procedure exploiting CPE was proposed for separating and determining silver ions in water and sand samples. All reagents and solvents were safe for the environment. Outstanding limits of detection and quantification, and analytical recovery were attained. The procedure involves a short separation and preconcentration time (10 minutes). For the analysis of several samples with different concentrations, the advantages of combining CPE (easy, safe, rapid, and efficient) and the solvation process utilizing a lipophilic agent (selectivity and sensitivity) for silver ions were demonstrated. For the fast extraction of silver in biological samples, the developed strategy produced excellent results in terms of selectivity, environmental safety, simplicity, and accuracy.

\section{Conflicts of interest}

The authors declare no conflict of interest.

\section{Acknowledgements}

The authors gratefully acknowledge financial support from Al-Furat Al-Awsat Technical University and the College of Medical Technology at The Islamic University of Najaf.

\section{REFERENCES}

1. Al-Mulla, E. A. J.; Nor, A. B. I.; Kamyar, S.; Mansor, B. A.; Wan, M. Z. W. Y. Res. Chem. Intermed., 2013, 39, pp 1313-1321 (https://doi.org/10.1007/s11164-012-0687-6).

2. El Sheikh, R.; Shaltout, M.; Nabawy, K. E.; Gouda, A. A. Anal. Bioanal. Chem. Res. 2020, 7, pp 49-60 (https://doi.org/10.22036/ABCR.2019.176629.1324).

3. Azooz, E. A.; Wannas, F. A.; Jawad, S. K. Res. J. Pharm. Technol., 2021, 14 (2), pp 594-598 (https:// doi.org/10.5958/0974-360X.2021.00106.2).

4. Tavakoli, L.; Yamini, Y.; Ebrahimzadeh, H.; Nezhadali, A.; Shariati, S.; Nourmohammadian, F. J. Hazard. Mater., 2008, 152, pp 737-743 (https://doi.org/10.1016/j.jhazmat.2007.07.039).

5. Qing, Y.; Hang, Y.; Wanjaul, R.; Jiang, Z.; Hu, B. Anal. Sci., 2003, 19, pp 1417-1420 (https://doi. org/10.2116/analsci.19.1417).

6. Yin, P.; Xu, Q.; Qu, R.; Zhao, G.; Sun, Y. J. Haz. Mat., 2010, 173, pp 710-716 (https://doi.org/10.1016/j. jhazmat.2009.08.143).

7. Wannas, F. A.; Ebaa, A. A.; Shawket, K. J. J. Adv. Res. Dynam, Cont. Sys., 2019, 11 (7), pp 260-269 (https://www.jardcs.org/archivesview.php?volume=1\&issue=14\&page=2).

8. Jawad, S. K.; Hameed, S. M.; Hussain, S. A. Orient. J. Chem., 2017, 33 (5), pp 2421-2429 (http:// dx.doi.org/10.13005/ojc/330535). 
9. Jawad, S. K.; Azooz, E. A. FIRE J. Sci. Tech., 2015, 3, pp 261-273 (http://dx.doi.org/10.13140/ RG.2.2.25154.48322).

10. Al-Mulla, E. A. J.; Al-Janabi, K. W. S. Chin. Chemi. Let., 2011, 22 (4), pp 469-472 (https://doi. org/10.1016/j.cclet.2010.10.037).

11. Ojeda, C. B.; Rojas, F. S.; Pavón, J. M. C. Am. J. Anal. Chem., 2012, 3, pp 125-130 (http://dx.doi. org/10.4236/ajac.2012.32018).

12. Ebaa, A. A.; Rana, K. R.; Hawraa, A. A. Nano Biomed. Eng., 2021, 13 (3), pp 70-88 (http://nanobe.org/ Data/View/710).

13. Sahar, A. H.; Safa, M. H. J. Eng. Appl. Sci., 2019,14 (5), pp 1005-1011 (http://www.arpnjournals.org/ jeas/research_papers/rp_2019/jeas_0319_7646.pdf).

14. Jawad, S. K.; Kadhium, M. U.; Azooz, E. A. Eurasian J. Anal. Chem., 2018, 13 (5), pp 1-11 (http://www. eurasianjournals.com/data-cms/articles/20210906034551pm94973.pdf).

15. Ebaa, A. A.; Jihan, R. M.; Shawket, K. J. Biochem. Cell. Arch., 2020, 20 (1), pp 2641-2648 (https:// www.connectjournals.com/file_html_pdf/3154301H_2641A.pdf).

16. Jawad, S. K.; Abed, A. S. Chem. Proc. Eng. Res., 2015, 33, pp 22-31 (https://iiste.org/Journals/index. php/CPER/article/view/22210).

17. Jawad, S. K.; Azooz, E. A. Journal of Research in Applied, Natural and Social Sciences, 2015, 1 (2), pp 119-134 (https://portal.arid.my/Publications/3cb5abd1-23f7-47.pdf).

18. Tozo, M. L. L.; Pinheiro, F. C.; Nóbrega, J. A. Braz. J. Anal. Chem., 2021, 8 (31), pp 74-88 (http:// dx.doi.org/10.30744/brjac.2179-3425.AR-50-2020).

19. Ahmed, F. K.; Shaymaa, I. S. Inter. J. Sci. Res., 2016, 5 (4), pp 218-222 (www.ijsr.net).

20. Shawket, K. J.; Kadhium, M. U.; Ebaa, A. A. J. Eng. Appl. Sci., 2019, 14 (11), pp 3514-3521 (https:// doi.org/10.36478/jeasci.2019.3514.3521).

21. Jawad, S. K.; Kadhim, M. O.; Azooz, E. A. Orient. J. Chem., 2017, 33 (4), pp 1879-1889 (http://dx.doi. org/10.13005/ojc/330433).

22. Jawad, S. K.; Hayder F. H. International Journal of Applied Chemical Sciences Research, 2015, 3 (1), pp 63-72 (http://ijacsr.com/).

23. Ahmed, F. K.; Mouyed, K. H.; Hasan, F. A.; Ahmed, S. A. Indones. J. Chem., 2019,19 (3), pp 638-649 (https://doi.org/10.22146/ijc.35681).

24. Jawad, S. K.; Ebaa, A. A. Inter. J. Sci. Tech., 2014, 9 (1), pp 17-23 (https://ijst-jo.com/wp-content/ uploads/2020/08/IJST-vol9-No.1-Mar.2014-a.pdf).

25. Wael, I. M.; Mohamed, M. H.; Ahmed, A. E. Egyptian Journal of Basic and Applied Sciences, 2014, 1 (3-4), pp 184-191 (http://dx.doi.org/10.1016/j.ejbas.2014.07.001).

26. Azooz, E. A.; Moslim, J. R.; Hameed, S. M.; Jawad, S. K.; Al-Mulla, E. A. J. Nano Biomed. Eng., 2021, 13 (1), pp 62-71 (http://dx.doi.org/10.5101/nbe.v13i1.p62-71).

27. Shawket, K. J.; Kadhim, M. O.; Alwan, A. S. Orient. J. Chem., 2017, 33 (4), pp 1985-1993 (https://doi. org/10.13005/ojc/330445).

28. Rahman, M. A.; Kaneco, S.; Amin, M. N.; Suzuki, T.; Ohta, K. Talanta, 2004, 62 (5), pp 1047-1050 (https://doi.org/10.1016/j.talanta.2003.10.035).

29. Kareem, A. N.; Wael, I. M.; Tamer, E. H.; Ibrahim, M. M. K.; Yasmeen, G. A. E. Heliyon, 2021, 7 (1), e06062 (https://doi.org/10.1016/j.heliyon.2021.e06062)

30. Haider, A. J.; Mohammed, M. R.; Al-Mulla, E. A. J.; Ahmed, D. S. Rend. Fis. Acc. Lincei, 2014, 25, pp 403-407 (http://dx.doi.org/10.1007/s12210-014-0300-6).

31. Shameli, K.; Ahmad, M. B.; Al-Mulla, E. A. J.; Shabanzadeh, P.; Bagheri, S. Res. Chem. Intermed., 2015, 41 (1), pp 251-263 (https://doi.org/10.1007/s11164-013-1188-y).

32. Zengin, H. B.; Gürkan, R. J. Food Comp. Anal., 2021, 98, 103814 (https://doi.org/10.1016/j. jfca.2021.103814).

33. Shemirani, F.; Kozani, R. R.; Assadi, Y. Microchim. Acta, 2007, 157, pp 81-85 (http://dx.doi.org/10.1007/ s00604-006-0654-2). 
34. Shemirani, F.; Jamali, M. R.; Kozani, R. R.; Niasari, M. S. J. Anal. Chem., 2006, 61, pp 124-128 (https:// doi.org/10.1134/S1061934806020067).

35. Naeemullah; Kazi, T. G.; Afridi, H. I.; Shah, F.; Arain, S. S.; Brahman, K. D.; Ali, J.; Arain, M. S. Arab. J. Chem., 2016, 9, pp 105-113 (http://dx.doi.org/10.1016/j.arabjc.2014.10.027).

36. Yang, X.; Jia, Z.; Yang, X.; Li, G.; Liao, X. Saudi Journal of Biological Sciences, 2017, 24, pp 589-594 (http://dx.doi.org/10.1016/j.sjbs.2017.01.030).

37. Tavallali, H.; Yazdandoust, S.; Yazdandoust, M. Clean - Soil Air Water, 2010, 38, pp 242-247 (https:// doi.org/10.1002/clen.200900207).

38. Wimmer, A.; Urstoeger, A.; Hinke, T.; Aust, M.; Altmann, P. J.; Schuster, M. Anal. Chim. Acta, 2021, 1150, 238198 (https://doi.org/10.1016/j.aca.2021.01.001).

39. Sabzevari, M. H. International Journal of ChemTech Research, 2013, 5 (1), pp 101-104 (https://www. scopus.com/inward/record.url?eid=2-s2.0-84873041691\&partnerID=10\&rel=R3.0.0).

40. Manzoori, J. L.; Nezhad, G. K. Anal. Chim. Acta, 2003, 484 (2), pp 155-161 (https://doi.org/10.1016/ S0003-2670(03)00343-X).

41. Wael, I. M. Microchem. J., 2020, 157, 105055 (https://doi.org/10.1016/j.microc.2020.105055).

42. Marczenko, Z.; Balcerzak, M. Separation, preconcentration and spectrophotometry in inorganic analysis. Elsevier, Amsterdam, 2000, chapter 46, p 439.

43. Mehrorang, G.; Ardeshir, S.; Khodabakhsh, N.; Ebrahim, N.; Asma, N.; Mustafa S. J. of Hazard. Mater., 2009, 168, pp 1022-1027 (https://doi.org/10.1016/j.jhazmat.2009.02.130).

44. Ghali, A. A. International Journal of Drug Delivery Technology, 2020, 10 (3) pp 459-464 (https://doi. org/10.25258/ijddt.10.3.27).

45. Gao, Y.; Wu, P.; Li, W.; Xuan, Y.; Hou, X. Talanta, 2010, 81, pp 586-590 (https://doi.org/10.1016/j. talanta.2009.12.038). 